\title{
Assessing Hungary's Stance on Migration and Asylum in Light of the European and Hungarian Migration Strategies'
}

\author{
KRISZTINA JUHÁSZ
}

$\frac{\text { DE }}{\mathrm{G}} \stackrel{\text { DE GRUYTER }}{\mathrm{OPEN}}$

Politics in Central Europe (ISSN: 1801-3422)

Vol. 13, No. 1

DOI: 10.1515/pce-2016-0021

\begin{abstract}
The European Union and its member states are facing one of their biggest challenges in recent years due to the surge in migration. This crisis saw more than a million migrants and refugees cross into Europe in 2015. Solutions and policies have been advanced at both the European and national levels, keeping in mind that migration policy is an area of shared competence under Article 4 of the Treaty on the Functioning of the European Union (TFEU). On 13 May 2015, the EU adopted the European Agenda on Migration, which set out immediate and medium-term actions designed to tackle the crisis more effectively. Earlier, in October 2013, the Hungarian government adopted its own migration strategy. The first part of this study provides some insight into the aims and measures contained in the European and Hungarian migration strategies. In the second part, I focus on the steps taken by the Hungarian government regarding asylum policy and crisis management. I conclude that the actions and communications of the Hungarian government are contrary to both these strategic documents.
\end{abstract}

Keywords: Hungary, European Union, migration, quota system, referendum

\section{Introduction}

In 2015, Europe and the European Union experienced an extraordinary wave of migration stemming from conflict or crisis zones like Syria, Afghanistan, Iraq, Libya, Eritrea and Somalia. While this situation did not begin in 2015,

1 This article is an extended version of a lecture presented at the 21st Central European Political Science Association Conference "Challenges for Political Leaders in Central and Eastern Europe," 3-4 June 2016 in Ljubljana, Slovenia. 
it reached its peak in that year. After the Lampedusa tragedy in October 2013, members of the European Union including Italy, Malta and Spain had called for common European measures, but no significant steps were taken. In 2014, however, the new Jean-Paul Juncker-led European Commission announced ten priority areas, including migration, and Dimitris Avramopoulos was appointed as Commissioner for Migration, Home Affairs and Citizenship. Another tragedy that saw the deaths of more than 800 people on the Mediterranean Sea in February 2015 led to the development of common European steps to handle the migrant crisis. As a result, on 13 May 2015, the European Commission adopted a strategic document, the European Agenda on Migration, which proposed several immediate actions along with other medium- and long-term measures.

The year 2015 was also an extraordinary time for Hungary with regard to migration. The number of asylum seekers who crossed Hungarian borders irregularly during the year reached 177,135 , up from 42,777 in the previous year and 18,900 in 2013 (Central Hungarian Statistics Office, 9 May 2016). Faced with the extreme level of this intake, the Hungarian government introduced several measures which proved contrary both to the plan under the European Agenda on Migration and to the government's own migration strategy adopted in 2013.

The first part of this article surveys the goals and measures contained in these strategic EU and Hungarian government documents. In the second part, I turn to the concrete steps taken by the Hungarian government since the spring of 2015, including its anti-migrant-and-asylum-seeker poster campaign, its national consultation on migration, the decision to erect a barbed wire fence at Hungary's southern border and amendments to asylum and criminal laws. Finally, in the concluding section, I argue that the Hungarian government's actions contradict the goals and measures under the European Agenda on Migration and the Hungarian migration strategy as well, in some cases, as European and international obligations.

\section{European Agenda on Migration}

The immediate actions under the European Agenda address the need for a swift and resolute response to the humanitarian tragedy unfolding across the entire Mediterranean region. The medium- and long-term measures mainly deal with the origins of the migration crisis and aim to strengthen common immigration, asylum and border management policies. The following table summarises the immediate, medium- and long-term measures identified in the European Agenda on Migration: 


\section{Table 1: The Hungarian Strategy on Migration}

\section{European Agenda on Migration}

\begin{tabular}{|l|}
\hline Immediate Actions \\
\hline Saving lives at sea: \\
- The budget for the Triton and Poseidon Fron- \\
tex missions is tripled in 2015 and 2016.
\end{tabular}

Medium- and Long-Term Measures

Reducing the incentives for irregular migration:

- Bilateral and regional cooperation frameworks on migration should be established across origin and transit states; these should include common efforts to combat criminal smuggling networks and to develop return and re-admission processes.

- With a budget allocation of EUR 96.8 billion over the 2014-2020 period, cooperation assistance outside the EU, particularly development-related cooperation, will play an important role in tackling the root causes of migration.

Targeting criminal smuggling networks:

- Common Security and Defence Policy (CSDP) operations should identify, capture and destroy vessels used by smugglers.

\section{Border management - saving lives and securing external borders:}

- Strengthening Frontex's role and capacity is crucial for ensuring safer external borders.

- The "Smart Borders" initiative aims to increase the efficiency and safety of border crossings through better use of relevant information systems (EURODAC, Visa Information System and Schengen Information System).

\section{Responding to high volumes of arrivals within the EU/ relocation:}

- Proposed legislation will activate the emergency plan under Article 78(3) of the Treaty on the Functioning of the European Union, including a temporary distribution system for persons in clear need of international protection. The goal is to assist Italy and Greece and ensure the fair and balanced participation of all member states.

- A permanent relocation system is proposed for emergency situations.

\section{Developing a common approach to the} protection of displaced persons in need/resettlement:

- Developing an EU resettlement scheme is recommended. This should support the global relocation of displaced persons who are in clear need of international protection from outside the EU.

\section{Europe's protection duty - establishing} a strong common policy on asylum:

- The EU needs a clear system for receiving asylum seekers inside its borders, and member states must implement this system fully and coherently.

- The "Dublin System" should be revised to ensure a more balanced allocation of responsibilities when examining asylum applications.

- The role of the European Asylum Support Office should be enhanced.

\section{New policy on legal migration:}

- The EU needs to identify economic sectors that face, or will face, recruitment problems or skill gaps.

- The European Blue Card scheme should be evaluated and overhauled.

- Visa policy should be updated by revising the Visa Code and establishing a new type of travel visa. 
Working in partnership with third countries to tackle migration upstream:

- The EU should provide help to origin and transit countries via development and protection programmes, particularly in Africa and the Middle East (EUR 30 million is allocated for this purpose under the 2015/2016 EU budget with complementary contributions to be made by member states).

- A pilot multi-purpose centre should be set up in Niger to ensure the provision of information, local protection and resettlement opportunities for those in need.

Using EU tools to help frontline member states/ Developing a hotspot system:

- The European Asylum Support Office, Frontex and Europol will work on the ground with frontline member states to swiftly identify and register incoming migrants and record their fingerprints. Hotspots will play an essential role in the relocation and resettlement processes.

The Hungarian government adopted its own migration strategy on 4 October 2013. ${ }^{2}$ This strategy had two objectives:

- To set out in a single document all the relevant circumstances to be considered during national legislative work related to migration, with due respect to the rules and recommendations of the European Union; and

- To foster open-minded and receptive social attitudes towards migration (Government Decree 1698/2013. (X.4): 4).

According to the strategy's principles, Hungary should:

- support all forms of regular migration;

- honour its European and international undertakings and ensure international protection to asylum seekers;

- contribute to the integration of regular migrants and persons afforded international protection;

- provide effective help and protection to stateless people;

- make a determined effort to eliminate illegal migration and abuses regarding residency; and

- ensure the availability of credible information about migration to the Hungarian public through effective communication aiming to decrease prejudice and stereotypes (Government Decree 1698/2013. (X.4): 5).

2 Government Decree 1698/2013. (X.4) 
Given the subject matter of this study, my focus is solely on the sections of the strategy that cover illegal migration and international protection. Concerning illegal migration, the document states that Hungary must deal with dual challenges as a transit country since, on the one hand, more economically developed EU Member States provide a serious incentive for migrants to cross the country and, on the other, the shortcomings of Greece's migration system (the latter is alluded to but not named) increase migration pressures on Hungary. Citing the Hungarian security strategy, the document points out that migration is a natural but complex phenomenon incorporating economic and demographic advantages and public and national security risks (Government Decree 1698/2013. (X.4): 41). The migration strategy stresses the need to ensure that extremist groups do not exploit existing prejudice and the lack of appropriate information about migration in Hungarian society (Government Decree 1698/2013. (X.4): 46). The aim instead is to provide new, more humane detention centres that enable free movement with strong external security and include appropriate facilities for vulnerable persons such as unaccompanied minors, pregnant women and sick and old people (Government Decree 1698/2013. (X.4): 49-50).

On the issue of asylum, the strategy's starting point is the solidarity of Hungary with foreign persons who are threatened with persecution for reasons of race, ethnicity, religion or politics. As such, the country undertakes to receive and protect those who have fled from war or other serious harm or who are stateless. Municipalities, it notes, should be motivated to receive asylum seekers and to allow the building of refugee camps on their land. To this end, the document introduces a quota system and other incentives designed to increase municipalities' readiness to receive asylum seekers (Government Decree 1698/2013. (X.4): 62). At the same time, it holds that as a matter of international solidarity, Hungary supports other countries that are suffering under the pressures of extraordinary migration; the country undertakes to set up and maintain national relocation and resettlement programmes (Government Decree 1698/2013. (X.4): 63). A key goal here is the development of more transparent procedures that will ensure these routes are accessible to all asylum seekers and that international protection is available to all in need (Government Decree 1698/2013. (X.4): 64).

\section{The Hungarian government's actions and communications during the migration crisis}

\section{Anti-migrant campaign and the national consultation on migration}

In the spring of 2015, an anti-migrant billboard campaign began to present openly hostile and exclusionary messages about immigration to the Hungar- 
ian public. Given the messages on these billboards ("If you come to Hungary, you must respect our culture," "If you come to Hungary, you must abide by our laws," "If you come to Hungary, you cannot take our jobs") and the fact that all of them were written in Hungarian, it is safe to conclude that Hungarian people were the target of the campaign.

In May 2015, the government also launched a national consultation on immigration and terrorism. Nearly 8 million constituents received a consultation paper along with a letter from Prime Minister Viktor Orbán. In the letter, the PM recalled the terrorist attack on the editorial staff of Charlie Hebdo in January 2015. At the same time, he drew a direct causal link between immigration and terrorism and noted that the European Union and Brussels had failed to tackle illegal immigration in an appropriate way. Alongside the threat of terrorism, Orbán stressed that immigrants were crossing the border illegally and pretending to be refugees when their real goal was accessing social benefits and job opportunities; as such, he claimed that they were a threat to the jobs and livelihood of the Hungarian people. Since European responses to immigration had proven ineffective, the PM stated that Hungary had to do things its own way (National Consultation on Immigration and Terrorism/Letter of Prime Minister Viktor Orbán, 9 May 2016). At a press conference on 27 July 2015, Hungarian government spokesperson Zoltán Kovács outlined the results of the consultation. According to his statement, 1,254,000 of nearly 8 million consultation papers had been returned to the government while an additional 58,000 had been submitted online. The vast majority of respondents, Kovács claimed, concurred that the threat of terrorism was on the rise and that Brussels's immigration policy had failed and a stricter immigration policy was needed. More than 93 per cent, he said, were in full agreement that instead of immigrants, Hungarian families should receive funding.

This consultation was the target of considerable criticism. Some of these critiques concerned the cost of the consultation process, which totalled almost 1 billion forints ( 960 million). Others pointed out that the results were not representative since only 1.25 million of 8 million surveys had been returned. In an open letter protesting the consultation, forty-five social scientists stated that the process had been manipulative and the Hungarian government had used a public opinion poll as a shield for political communication. The main aim, they noted, was political mobilisation against migrants and refugees (hvg.hu 2016).

In fact, the Hungarian government proceeded to use the results of the consultation to legitimate its actions. These included the building of a barbed wire border fence and the amendment of the country's Asylum Act, the Criminal Code and the Criminal Procedure Act. 


\section{The barbed wire border fence}

Due to the increase in migrants and asylum seekers crossing the Hungarian border from Serbia in the first half of $2015,{ }^{3}$ on 17 June 2015, the Hungarian government decided to close its "green" border with Serbia. Under the government's decree, a 175-km long and 4-metre high steel and barbed wire fence was to be erected along the border with Serbia as a temporary solution to the crisis. ${ }^{4}$ On 6 July 2015, Hungarian parliament amended the State Border Act to allow for the acquisition of land ten metres from the state border for the building and maintenance of a barbed wire border fence with due compensation to the landowner concerned. On 13 July 2015, the Hungarian army began to build a sample section of the fence in Mórahalom; ${ }^{5}$ this 175-metre long section was finished five days later on 18 July. While the original plan had been to finish building the fence by 30 November 2015, PM Viktor Orbán brought the deadline forward to 31 August during a speech he gave in Bálványos. The green border between Hungary and Serbia was finally sealed off on the evening of 14 September 2015. The following day, Hungarian Foreign Minister Péter Szijjártó announced the government's plans to build a fence along the Hungarian-Romanian border, and three days later, on 18 September, PM Viktor Orbán revealed that a 41-km long barrier would also be erected on the Hungarian-Croatian border. Work on that fence began the same day.

The decision to build a barbed wire border fence triggered heated reactions both from within Hungary and in the international community. Aside from the governing parties (Fidesz Hungarian Civic Alliance-the Christian Democratic People's Party, Fidesz-KDNP), only the far right radical Jobbik supported this plan. In contrast, the so-called democratic opposition parties - the Hungarian Socialist Party (MSZP), Democratic Coalition (DK), Politics Can Be Different (LMP), Together (Együtt) and Dialogue for Hungary (PM) - all condemned the border closure. Turning to international reactions, the day after the Hungarian announcement of the border wall, on 18 June 2015, the Serbian Prime Minister Alexandar Vucic expressed his shock and surprise. Building walls, he said, was not the solution and Serbians did not want to live in Auschwitz. A spokesperson for the European Commission, Natasha Bernaud said: "We have only recently taken down walls in Europe; we should not be putting them up" (Anastasijevic 2015).

As for the statistics on irregular border crossings, immediately before the wall was built, i.e. during the summer of 2015 and up to mid-September, between 1500 and 3000 migrants crossed the border from Serbia daily. After the

3 More than 57,000 asylum seekers entered the country in the first half of 2015 according to the Director of the Office of Immigration and Nationality. http://24.hu/belfold/2015/06/17/iden-57-ezer-menekult-erkezett-magyarorszagra/ (18 May 2016)

4 Government Decree 1401/2015. (VI. 17.)

5 Mórahalom is a small city close to the southern border of Hungary. 
border closures (and bearing in mind that Hungary's border with Croatia was shut down in the same way in October 2015), the number of irregular border crossings dropped dramatically. In contrast, the number of migrants intercepted for illegal border crossings has recently been put at between 150 and 250 per day, a rate very similar to the one in the spring of $2015 .^{6}$

\section{Amendment to the Asylum Act and related rules}

Hungarian parliament made two amendments to the Asylum Act in 2015, with the first coming in July and the second in September. Both these amendments introduced provisions that undermine the availability of asylum in Hungary. As such, they are contrary to EU law and the guidelines of the European Court of Human Rights and the United Nations High Commissioner for Refugees (UNHCR).

In July 2015, the Hungarian Asylum Act $^{7}$ and its implementing regulation, the Government Decree on Asylum ${ }^{8}$ were amended. Furthermore, the Hungarian government approved a list of "safe" countries of origin and "safe" third countries. ${ }^{9}$ These new rules entered into force on 1 August 2015, bringing several worrying changes:

- Government Decree 191/2015 (VII. 21) identifies Serbia as a safe third country for asylum seekers, resulting in the quasi-automatic rejection ${ }^{10}$ of over $99 \%$ of asylum claims since almost all asylum seekers enter Hungary from Serbia. Both the Hungarian Supreme Court (Kúria) and the UNHCR have found that Serbia is not a safe third country for asylum seekers.

- The amendment to the Asylum Act allows for the accelerated processing of cases where a "safe" third country is available to the asylum seeker.

- The judicial review of Office of Immigration and Nationality (OIN) decisions is also problematic since in most cases this process does not automatically suspend the enforcement of decisions (Hungarian Helsinki Committee: No Country for refugees 2015: 1-2.).

On 4 September 2015, Hungarian parliament again made comprehensive amendments to the Asylum Act under hastily adopted legislation. The new

6 See the Hungarian police website reports on the daily number of intercepted migrants: http:// www.police.hu/hirek-es-informaciok/hatarinfo/elfogott-migransok-szama-lekerdezes?honap[value] [year] $=2015$ \& honap[value][month]=3

7 Act LXXX on Asylum, 2007.

8 Government Decree 301/2007 (XI.9.)

9 Government Decree 191/2015 (VII. 21)

10 Under Section 51 (2) (e) of the Asylum Act, "[a]n applicant's application will be deemed inadmissible if a third country qualifying as a safe third country exists for him or her." http://helsinki.hu/wp-content/ uploads/Asylum_Act_updated_14-September2015.pdf (10 May 2016) 
rules, which entered into force on 15 September, included the following problematic changes:

- A "border procedure" was introduced after the sealing off of the Hungarian-Serbian border by the barbed wire border fence. Under section 71/A (3) of the Asylum Act, the OIN must decide on the admissibility of asylum claims within eight days; this is an extremely short time frame for the examination of all required circumstances. Based on the interviews conducted by the members of the Hungarian Helsinki Committee and the Council of Europe Commissioner for Human Rights, in practice, the OIN decides on claims within a few hours and without examining their merits (Hungarian Helsinki Committee: No Country for Refugees 2015: 3 and Third Party Intervention by the Council of Europe Commissioner for Human Rights 2015:4). Furthermore, according to the Asylum Act, the border procedure is not applicable to asylum seekers with special needs, however since there is no established protocol for early identification of vulnerable people in the Hungarian asylum system, this procedural safeguard is not effective. Another problem is the lack of any permanent professional legal advice service in transit zones where processing occurs. According to the Hungarian Helsinki Committee, OIN staff in the Röszke transit zone have refused access to Committee members even though they represent the only Hungarian NGO providing free legal assistance to asylum seekers (Hungarian Helsinki Committee: No Country for Refugees 2015: 4).

- There are also questions about the effective judicial review of negative decisions on asylum because of several provisions of the Act: 1) the seven-day time limit for submitting appeals is considered exceedingly short by both the Hungarian Helsinki Committee and the Council of Europe Human Rights Commissioner; 2) the eight-day time limit for judicial reviews also appears short given the requirements under the EU Asylum Procedures Directive, i.e. "an effective remedy provides for a full and ex nunc examination of both the facts and points of law"; 3) there is no requirement for the personal involvement of asylum seekers during the judicial review process; 4) appeals against border processing decisions may be heard by judges' clerks who have not been appointed judges, and thus, do not enjoy judicial independence and have less judicial experience; and 5) since 15 September 2015, judges (and judges' clerks) have not been allowed to amend first-instance administrative decisions and may only overrule those decisions and refer them back for re-processing.

- The amendment to the Asylum Act introduces "mass migration crisis" provisions that allow the police and the army to be involved in the asylum process (See section 80/G of the Asylum Act). 
Alongside the protests and criticisms from the Hungarian Helsinki Committee, the Council of Europe Commissioner for Human Rights and the UNHCR, ${ }^{11}$ the European Commission also launched infringement proceedings against Hungary in December 2015, having found that the Hungarian legislation was in some instances incompatible with EU laws, in particular, the reframed Asylum Procedures Directive ${ }^{12}$ and the Directive on the Right to Interpretation and Translation in Criminal Proceedings. ${ }^{13}$ Regarding the asylum process, the European Commission has concerns that there is no opportunity to raise new facts and circumstances during the judicial review phase and that Hungary does not automatically suspend the implementation of decisions in the case of an appeal; asylum seekers are, thus, basically forced to leave the country before the deadline for lodging their appeal expires or before the appeal itself is heard. Additional problems include the fact that judicial decisions can be made by judges' clerks during the border procedure and that in-person hearings for applicants are only optional during judicial reviews. As regards the right to translation and interpretation during criminal proceedings, the Commission is concerned that this is not respected or safeguarded during fast-tracked criminal proceedings on irregular border crossings (European Commission - Press release Brussels, 10 December 2015).

A further amendment to the Asylum Act which entered into force on 5 July 2016 allows police to return all asylum seekers to so-called transit zones if they are captured within eight kilometres of the state border. The UNHCR and human rights organisations claim that these new rules do not endure the principle of non-refoulement and mean that asylum in Hungary is inaccessible. In particular, they note that 15-20 asylum seekers are let into transit zones daily while hundreds remain in front of the fence, sometimes waiting for weeks in fairly bad conditions.

\section{Amendment to the Criminal Code and the Criminal Procedure Act}

In parallel with the construction of a barbed wire border fence and amendment of asylum rules, Hungarian parliament modified the Criminal $\operatorname{Code}^{14}$ and the Act on Criminal Procedure. ${ }^{15}$

The amendment to the Criminal Code introduced three new crimes:

11 Even before the amendment of these asylum rules, the UNHCR had expressed concerns. In particular, it noted that the new asylum system would make it impossible for people fleeing war and persecution to seek safety in Hungary. See: Baloch, Babar (2015): 'UNHCR urges Hungary not to amend asylum system in haste', UNHCR website, http://www.unhcr.org/559641846.html (18 May 2016)

12 Directive 2013/32/EU

13 Directive 2010/64/EU

14 Act C of 2012

15 Act XIX of 1998 
- Prohibited crossing of a closed border (Section 352/A): The basic offence of unauthorised entry into Hungarian territory protected by a closed border is punishable by up to three years' imprisonment. The aggravated forms of the crime attract the following sanctions: a) imprisonment for between one and five years if the offence is committed while armed or using a weapon or taking part in a riot; b) imprisonment for between two and eight years if the offence is committed while armed, using a weapon and taking part in a riot; or c) imprisonment for between five and ten years if the offence results in death.

- Causing damage to a closed border (Section 352/B): In the absence of another more serious offence, damaging or destroying a facility or instruments that provide state border security is punishable by between one and five years' imprisonment. The aggravated forms of the offence trigger the following penalties: a) imprisonment for between two and eight years if the offence is committed while armed or using a weapon or taking part in a riot; b) imprisonment for between five and ten years if the offence is committed while armed, using a weapon and taking part in a riot; and c) imprisonment for between ten and twenty years if the offence results in a death.

- Obstructing construction of a border fence (Section 352/C): In the absence of a more serious offence, this crime is punishable by up to one year of imprisonment.

Besides establishing these three offences, the amendment to the Criminal Code tightens penalties for crimes related to people smuggling in both the basic and aggravated forms.

Moreover, the amended Criminal Procedure Act introduces special rules applicable to the above crimes associated with the closed border. According to those rules:

- In the event of a mass migration crisis, criminal proceedings for border closure-related offences take priority over all other criminal proceedings. The Szeged Regional Court has exclusive jurisdiction over these fast-tracked proceedings and judges are to be appointed by the National Office of the Judiciary;

- As a general rule, courts should mainly order the house arrest of defendants, and this penalty should be applied in immigration or asylum detention centres; and

- Pre-trial detention should also take place in asylum or immigration facilities and in police lock-up.

Like the amended asylum laws, these new criminal regulations have attracted much criticism. The following points should be emphasised: 
- Probably the most fundamental concern is the fact that the new closed border-related offences criminalise migrants and asylum seekers without making any substantive decision on their asylum claims. In this respect, they are contrary to Article 31 of the Convention on the Status of Refugees, which states: "Contracting States shall not impose penalties, on account of their illegal entry or presence, on refugees who, coming directly from a territory where their life or freedom was threatened in the sense of article 1, enter or are present in their territory without authorisation, provided they present themselves without delay to the authorities and show good cause for their illegal entry or presence." As we have seen, the fact that Hungary considers Serbia to be a safe third country contradicts the practice of other EU Member States as well as the recommendations of the UNHCR ${ }^{16}$ and even the Hungarian Supreme Court's own guidelines. ${ }^{17}$

- As mentioned above, many actors including the European Commission are concerned about breaches to the right to translation and interpretation in the new fast-tracked criminal proceedings. The Hungarian Helsinki Committee points out: "There is no statutory requirement to provide a written translation of either the indictment or the sentencing part of the ruling, which is [a] direct violation of the relevant EU directive and of the right to [a] fair trial in accordance with the European Convention on Human Rights" (Hungarian Helsinki Committee 2015: 3).

- Since closed border-related crimes take priority over all other offences, we may expect that other criminal proceedings will be delayed. In this regard, the European Court of Human Rights has already ordered Hungary to pay compensation several times because of the duration of its criminal proceedings. The new rules will clearly only worsen the situation, slowing down other and, in most cases, more serious criminal proceedings.

16 In 2012, UNCHR recommended that Serbia not be recognised as a safe third country. [source]?

17 In December 2012, the Supreme Court provided its opinion on several questions related to the application of the safe third country concept. In this statement, the Supreme Court stressed that when reviewing administrative decisions on the application of the safe third country concept, courts should ex officio consider accurate and credible country information at their disposal at the time of the decision. In this context, the country information provided by United Nations High Commissioner for Refugees must always be taken into account. If there is no UNHCR country report available about a given country or that report is out-of-date, both the administrative authority and the court should specify this fact in their decision. The conclusion that a UNHCR country report is out-of-date must be justified in detail. Further, the Supreme Court added that the overburdening of a third country's asylum system may render that country incapable of respecting the rights of asylum seekers. Such a third country should not be regarded as safe for asylum seekers. For an unofficial translation of this opinion, see:http://helsinki.hu/ wp-content/uploads/HU-Supreme-Court-on-S3C-Dec-2012.pdf (18 May 2016) 


\section{Detention conditions and the closure of Debrecen refugee camp and asylum detention centre}

Recurring criticisms of the increased use of detention for asylum seekers and the usually poor conditions in asylum detention centres have also been raised by the UNHCR, the Council of Europe Commissioner for Human Rights, the Hungarian Helsinki Committee, Human Rights Watch and the Migrant Solidarity Group of Hungary (MIGSZOL). Even before the current crisis and the amendments to the Criminal Code and the Criminal Procedure Act, the UNHCR had observed that Hungary was treating asylum seekers like criminals, using detention as a standard rather than an exceptional measure for those who crossed the border irregularly. According to an Asylum Information Database's (AIDA) report on Hungary, between January and September 2015, the country detained 1,860 asylum seekers. As of 2 November 2015, 52 per cent of applicants for asylum in Hungary had been detained. On the same date, the number of asylum seekers who were being detained (441) exceeded the figure being accommodated in open reception centres (412) (AIDA Country Report on Hungary, November 2015: 59). Moreover, it was not only single men but families with children and vulnerable people (pregnant women, sick and disabled people and unaccompanied minors) who were being detained and kept behind bars typically for four to five months (UNHCR 2012).

The Council of Europe Commissioner for Human Rights has also emphasised the problem of the arbitrariness of detention orders. In particular, there are no clear criteria as to why some people are detained while others are sent to open reception facilities or allowed to continue on their journey to other EU member states (Third Party Intervention by the Council of Europe Commissioner for Human Rights 2015: 6).

Another pressing problem concerns the conditions in most asylum detention facilities and open reception centres. Human rights organisations such as Human Rights Watch, the Hungarian Helsinki Committee and MIGSZOL report regularly on the inadequacy of these conditions, drawing on interviews with asylum seekers and their own visits to open camps and detention centres. Key issues here include:

- Overcrowding in detention and open facilities. While three detention centres (Békéscsaba, Debrecen and Nyírbáto) had a combined capacity of 472 places (Asylum Information Database Country Report on Hungary November 2015: 59), 2393 asylum seekers were detained there in 2015 (Office of Immigration and Nationality Kiadványfüzet, 2014-2015). The government's decision to close the biggest refugee camp (830 places) and its detention facility in Debrecen at the end of 2015 only worsened the situation. Another refugee camp in Nagyfa (300 places) stopped operat- 
ing in February 2016, and a new camp was opened in Körmend near the Austrian border in May with a capacity of 300-500 persons.

- There is no psychosocial support available in any of the detention centres; open air spaces are typically very small and insufficiently equipped (Asylum Information Database: Conditions in Detention Facilities).

- In Békéscsaba and Nyírbátor, detained asylum seekers are handcuffed while being escorted from the detention centre to a court, hospital or bank (Asylum Information Database: Conditions in Detention Facilities).

- In Békéscsaba, some toilets lack doors and some taps are non-operational, meaning that access to hot water is not ensured (Asylum Information Database: Conditions in Detention Facilities).

- Detainees in the Nyírbátor detention centre have complained of bedbug infestations (Human Rights Watch: Hungary: Locked Up for Seeking Asylum 2015).

\section{Hungary and the compulsory quota system}

Under the European Agenda on Migration, the European Commission had proposed temporary and permanent mandatory distribution schemes for the benefit of persons in clear need of international protection; the aim was to ensure the fair and balanced participation of all member states in this common effort. On 27 May and 9 September 2015, the Commission approved its first and second implementation packages under the Agenda, including proposed legislation on the relocation of 40,000 and 120,000 people, respectively, based on the emergency response system under Article 78(3) TFEU. ${ }^{18}$ In line with the Commission's proposals, on 14 and 22 September 2015, the Council decided to take provisional measures concerning international protection for the benefit of Italy and Greece. ${ }^{19}$ Importantly, this emergency relocation system is temporary and Council Decision (EU) 2015/1601 only applies for the two years until 26 September 2017. Under this temporary system, 1294 persons should be relocated to Hungary during the two-year period, as described in the annexes of the decision. Nevertheless, as of 2 October 2016, 6013 people had been relocated from Italy and Greece to other member states, but Hungary and Poland had not received any asylum seekers (European Commission 2016).

From the very beginning, the Hungarian government rejected the Commission's emergency relocation proposals and the Council's decision. In November 2015, Hungarian parliament authorised the government to seek a review of the

18 This provision holds that in the event that one or more member states faces an emergency situation due to the sudden influx of nationals from third countries, then based on a proposal from the Commission, the Council may adopt provisional measures for the benefit of the member state(s) concerned. When taking such action, it must first consult European Parliament.

19 Council Decision (EU) 2015/1523 and 2015/1601 
legality of Council decisions from the European Court of Justice (ECJ). On 4 December 2015, Hungarian Justice Minister László Trócsányi announced that the government had launched legal action contesting the Council's decisions. ${ }^{20}$ Speaking during the parliamentary debate on the ECJ application and again at a press conference, Trócsányi noted that Council decisions are imposed norms which lack any kind of social legitimacy since most of Europe's population does not agree with them. Furthermore, these decisions, he said, contain multiple legal errors including their violation of the principle of subsidiarity and disregard for the rights of national parliaments vis-à-vis European legislation. Hungary has also raised questions about the existence of a proper legal basis for the Council's decisions (Trócsányi 2015).

Alongside the preparation of this suit against the quota decisions, at the beginning of November 2015, the governing party Fidesz started a petition campaign entitled "Save the Country!" against the mandatory quotas. On 30 November 2015, government spokesperson Zoltán Kovács stated at a press conference that more than 900,000 people had signed the petition, a result which, he claimed - together with the findings of the national consultation on migration and terrorism - showed that 85 to 90 per cent of the public were against the mandatory distribution scheme (Kovács 2015). Nevertheless, as with the results of the national consultation, these were questions of representativeness: Of the 8 million voters at issue, only 1.25 million had returned the consultation paper (and not all of them had replied as directed) while only 900,000 had signed the Fidesz petition.

Furthermore, the European Agenda on Migration had suggested establishing a mandatory permanent relocation system, and the Commission adopted a detailed proposal to that effect on 9 September 2015. According to this proposal:

Such mechanism should be rapidly triggered in respect of any Member State that experiences crisis situations of such a magnitude as to put under significant strain even well prepared and functioning asylum systems, also taking into account the size of the Member State concerned. The proposed relocation mechanism aims, on the one hand, to ensure, in situations of crisis, a fair sharing of responsibilities between Member States for large numbers of applicants in clear need of international protection, and, on the other hand, the proper application of the Dublin system including the full protection of the rights of applicants for international protection (European Commission 2015: 2)

20 Hungary is not the only member state which is contesting the Council's decisions in the European Court of Justice. On 30 September 2015, the Slovak government also decided to take legal action and, on 2 December of the same year, it lodged its petition. 
As its response to the emergency relocation scheme would suggest, the Hungarian government was opposed to any kind of permanent mandatory distribution system for people in need of international protection. Speaking at a press conference on 24 February 2016, Prime Minister Viktor Orbán announced the Hungarian government's decision to call a referendum on the "compulsory resettlement quotas," noting that the head of Cabinet had already referred the referendum question to the National Election Commission for confirmation. The PM stated: "This means that the government holds that the right to decide on compulsory resettlement quotas may not be taken away from Hungarian parliament. No one besides ourselves - that is, the elected members of Hungarian parliament - may decide on this issue.[...] To date, no one has asked the European people whether they want, accept or reject the introduction of compulsory quotas.[...] I am convinced [...] that introducing compulsory resettlement quotas without the consent of the people is nothing less than an abuse of power"(Orbán 2016).

On 29 February 2016, the National Election Commission confirmed the referendum question in its decision 14/2016. The endorsed question read: "Do you agree that the European Union should have the power to impose the compulsory settlement of non-Hungarian citizens in Hungary without the consent of the National Assembly of Hungary?" At the same time, four petitions for the review of this administrative decision were lodged with the Supreme Court of Hungary, which decided on these filings on 3 May 2016. The Supreme Court considered three issues during these appellate proceedings:

- whether the referendum question referred to commitments under international agreements

- whether the question fell within the remit of Hungarian parliament

- whether the question was unambiguous

The Supreme Court found that the question complied with the Hungarian Constitution and the Referendum Act and it approved the relevant National Election Commission decision (Knk.IV.37.222/2016/9.sz decision of the Kúria/ the Hungarian Supreme Court).

The referendum was held on 2 October 2016, and the results showed that 98 per cent of participants had answered no to the question. Nevertheless, the process was declared invalid since only 41 per cent of votes were valid. That invalidity was largely due to the campaigns of democratic opposition parties and civil society organisations, who had urged Hungarians not to participate or to vote invalidly.

It is worth noting that the idea of holding a referendum on the quota system had originally been raised by Jobbik in October 2015. At that time, however, Lajos Kósa, the leader of Fidesz's parliamentary group said at a press conference that this was a question about Hungary's international commitments and, as 
such, it could not be the subject of a referendum under the country's constitutional rules (Mandiner 2016). Later, Jobbik suggested that instead of holding a referendum, Hungary should amend its Constitution in order to prohibit the resettlement of migrants without the consent of Hungarian parliament (Thüringer 2016).

Given this background, the next developments were most interesting: Prime Minister Orbán announced an amendment to the Constitution as a result of the otherwise invalid referendum. The core of his statement was as follows:

Foreigners may not be placed in Hungary. Foreigners - with the exception of citizens of the European Economic Area - are allowed to live on Hungarian territory based on applications which are individually assessed by the Hungarian authorities under the procedures defined in laws accepted by Hungarian parliament.

In other words, the ideas for both the referendum and the constitutional amendment were taken over from Jobbik.

\section{Conclusions}

Having reviewed both the proposals of the European Agenda on Migration and the principles and plans under Hungary's own migration strategy, it is quite clear that the measures taken by the Hungarian government since the beginning of 2015 contradict both these documents. Furthermore, in some cases, the Hungarian measures even flout European and international commitments:

- The xenophobic tone and messaging of the anti-migrant billboard campaign, the national consultation and the 2016 referendum campaign were contrary to the aims and objectives of Hungary's migration strategy, i.e. fostering open-minded and receptive social attitudes to migration and ruling out the potential use and exploitation of prejudice and lack of appropriate information about migration among the Hungarian population;

- The amendments to the Asylum Act and other associated rules contravene both European and international asylum policy standards since they mean that asylum and international protection in Hungary is barely accessible to asylum seekers, the non-refoulement principle cannot prevail and the special needs and treatment of vulnerable persons are not guaranteed;

- The criminalisation of asylum seekers who enter the country irregularly is contrary to the Convention on the Status of Refugees. At the same time, breaches of the right to translation and interpretation in fast-tracked criminal proceedings are out of step with the Directive on the Right to Interpretation and Translation in Criminal Proceedings (Directive 2010/64/ $\mathrm{EU})$; 
- Hungary's opposition to the relocation scheme (quota system) at once undermines solidarity among member states and contravenes the Hungarian and European strategies on migration since both these documents see this scheme as an important part of immigration and asylum policy.

Confronted with these facts in a June 2015 interview, government spokesperson Zoltán Kovács replied that the previous migration strategy was out-of-date and had been overtaken by circumstances: "It has to be amended obviously. The government has still not given a formal order, but it will happen at one of the forthcoming government sessions" (Pintér 2015). It must be emphasised that there is still no new migration strategy in force in Hungary. It is also worth noting that the previous strategy was adopted in October 2013, when, as the document itself states, the increasing pressure of migration from the Balkans, North Africa and the Middle East was quite obvious (Government Decree 1698/2013. (X.4):42).

Instead of this Hungarian strategy on migration and the European Agenda on Migration, something else seems to be taking the place of Hungary's immigration and asylum policy. The Hungarian government's unilateral and widely criticised steps stem from its rivalry with far right populist party Jobbik and its wish to put certain themes on the political agenda. The price is the Hungarian government's failure to honour its international and European commitments when it comes to immigration and asylum.

\section{References}

Anastasijevic, Dejan (2015): 'Don't fence me in', euobserver opinion available at https://euobserver.com/opinion/129208 (10 May 2016)

Asylum Information Database (AIDA): Hungary: Country Report, November 2015 http://www. asylumineurope.org/reports/country/hungary (20 May 2016)

Asylum Information Database (AIDA): Conditions in Detention Facilities http://www.asylumineurope.org/reports/country/hungary/detention-asylum-seekers/detention-conditions/ conditions-detention(20 May 2016)

Baloch, Babar (2015): 'UNHCR urges Hungary not to amend asylum system in haste', UNHCR website, http://www.unhcr.org/559641846.html (18 May 2016)

Central Statistics Office of Hungary https://www.ksh.hu/docs/hun/xstadat/xstadat_eves/i_wnvn002b.html (9 May 2016)

Council of Europe (2015): 'Third Party Intervention by the Council of Europe Commissioner for Human Rights under Article 36 of the European Convention on Human Rights Application No. 44825/15 and No. 444944/15, S.O. v. Austria and A.A. v. Austria Strasbourg' (17 December), 
http://statewatch.org/news/2016/jan/echr-human-rights-intervention-austria-hungary-returns. pdf (11 May 2016)

European Commission (2015): 'Commission opens infringement procedure against Hungary concerning its asylum law' (press release) (10 December), http://europa.eu/rapid/press-release_IP-15-6228_en.htm (11 May 2016)

European Commission (2016), 'Member States' Support to Emergency Relocation Mechanism' (12 October) http://ec.europa.eu/dgs/home-affairs/what-we-do/policies/european-agenda-migration/press-material/docs/state_of_play_-_relocation_en.pdf (13 October 2016)

European Commission (2015): Proposal for a regulation of the European Parliament and of the Council establishing a crisis relocation mechanism and amending Regulation (EU) No. 604/2013 of the European Parliament and of the Council of 26 June 2013 establishing the criteria and mechanisms for determining the Member State responsible for examining an application for international protection lodged in one of the Member States by a third country national or a stateless person, http://eur-lex.europa.eu/resource.html?uri=cellar:92b8154b-56 cd-11e5afbf-01aa75ed71a1.0007.02/DOC_1\& format=PDF (22 May 2016)

Human Rights Watch (2015): ‘Hungary: Locked Up for Seeking Asylum' (1 December), https:// www.hrw.org/news/2015/12/01/hungary-locked-seeking-asylum (20 May 2016)

Hungarian Helsinki Committee (2015): No country for refugees - New asylum rules deny protection to refugees and lead to unprecedented human rights violations in Hungary, Information note 18 (September), http://helsinki.hu/wp-content/uploads/HHC_Hungary_Info_Note_Sept2015_No_country_for_refugees.pdf (11 May 2016)

Hungarian Helsinki Committee (2015): 'The Hungarian Helsinki Committee's opinion on the government's amendments to criminal law related to the sealed border' (16 September), http:// helsinki.hu/wp-content/uploads/modification-of-criminal-laws-16092015.pdf (11 May 2016)

Hungarian Supreme Court (Kúria) (2016): Knk.IV.37.222/2016/9.sz Decision of the Kúria, http:// net.jogtar.hu/jr/gen/hjegy_doc.cgi?docid=A16K0621.KUR \& timeshift=fffffff4 \& txtreferer=00000001.TXT (22 May 2016), hvg.hu (2016): 'Leírták, hogyan ver át bennünket a kormány konzultációs íve' available at http://hvg.hu/velemeny/20150430_Visszaeles_a_nemzeti_ konzultacio_tobb_tar\#rss (11 May 2016)

Kovács, Zoltán (2015): 'More than nine hundred thousand people have signed the petition against resettlement quotas', website of the Hungarian government (November 30) http:// www.kormany.hu/en/government-spokesperson/news/more-than-nine-hundred-thousand-people-have-signed-the-petition-against-resettlement-quotas (22 May 2016)

Mandiner (2016): 'Kósa: Nem lehet a migránskvótáról népszavazni', mandiner.migráció (24 February) available at http://migracio.mandiner.hu/cikk/20160224_kosa_nem_lehet_a_migranskvotarol_nepszavazni (22 May 2016)

National Consultation on Immigration and Terrorism, letter of Prime Minister Viktor Orbán. http://www.kormany.hu/download/7/e2/50000/nemzeti_konzultacio_bevandorlas_2015. pdf (9 May 2016) 
Office of Immigration and Nationality Kiadványfüzet 2014-2015 éves, available at: http:// www.bmbah.hu/index.php?option=com_k2 \& view=item \& layout=item \& id=177 \& Itemid=1232 \& lang=hu (20 May 2016)

Orbán, Viktor (2016): 'Hungarian government decides to call referendum on compulsory resettlement quotas', website of the Hungarian government (February 24) http://www.kormany. hu/en/the-prime-minister/news/hungarian-government-decides-to-call-referendum-on-compulsory-resettlement-quotas (22 May 2016)

Pintér, Bence (2015): 'Módosítani fogja a Migrációs Stratégiát a kormány', mandiner (30 June), available at: http://mandiner.hu/cikk/20150630_modositani_fogja_a_migracios_ strategiat_a_kormany (22 May 2016)

Thüringer, Barbara (2016): 'A Jobbik a kvótás népszavazás helyett alaptörvény módosítást akar', index (12 April): available at http://index.hu/belfold/2016/04/12/jobbik_kvota_nepszavazas_alaptorveny/ (22 May 2016)

Trócsányi, László (2015): 'Action to be filed in case of mandatory quotas may serve as precedent', website of the Hungarian government (17 November), http://www.kormany.hu/en/ministry-of-justice/news/action-to-be-filed-in-case-of-mandatory-quotas-may-serve-as-precedent (22 May 2016)

United Nations Refugee Agency (UNHCR) (2012) 'The UN Refugee Agency for Central Europe: Asylum-seekers treated like criminals in Hungary' (24 April), available at: http://www.unhcr-centraleurope.org/en/news/2012/asylum-seekers-treated-like-criminals-in-hungary.html (20 May 2016)

Krisztina Juhász is a senior lecturer in the Department of Political Science at the University of Szeged. Her main research interest is the Common Security and Defence Policy of the European Union.Email: juhaszk@polit.u-szeged.hu. 